\title{
Student Interaction and Communication Skills
}

\author{
Nathanael Sitanggang ${ }^{1}$, Putri Lynna A. Luthan ${ }^{2}$, Abdul Hamid $\mathrm{K}^{3}$ \\ \{nathanael.sitanggang@unimed.ac.id ${ }^{1}$ \} \\ Faculty of Engineering, Universitas Negeri Medan ${ }^{1,2,3}$
}

\begin{abstract}
This study aims to provide an overview of the communication and interaction skills of students in terms of major and gender groups. This research was conducted using survey methods at the UniversitasNegeri Medan (UNIMED). Student samples totaling 400 people were determined by purposive random sampling technique. Communication and interaction skillsdata are captured using a questionnaire with a Likert scale model with a reliability coefficient of 0.726 . Research findings are: (1) Communication and interaction skills of students tend to be in the medium category; (2) Students' communication and interaction skills can be influenced by major groups (natural science or social science) and gender.
\end{abstract}

Keywords: Communication skills, interaction skills, gender.

\section{Introduction}

Universities must continue to strive to develop communication skills and student interaction in learning, so that after the student has graduated, he can become a human resource with character. Lecturers are a very strategic part in developing student communication and interaction skills, because lecturers directly act as learning designers, instructors and mentors for students. As a designer, lecturers can integrate the components of communication and interacting skills in lecture plans and lecture contracts, thus students who attend lectures not only gain knowledge and hardskills, but students also have the skills to communicate and interact well. According to Soelistiyowati and Nugroho (2012) that communication and interaction skills are a component of building soft skills of a person. The author agrees with Elfindri, et al. (2010) who stated that growing soft skills in the world of education can be done in 3 (three) ways, namely: 1) soft skill design into the learning curriculum; 2) developing activities and activities of children in the dormitory or at home; and 3) developing soft skills in extra curricular activities. Thus, the implementation of soft skills is carried out through integration into the curriculum, namely through the learning process or lectures contained in the Semester Lecture Plan. From the description above, it can be seen that universities are very strategic in developing communication skillsand student interaction because they can be integrated bylecturers in learning practices and through example. Therefore, the description of students communication and interaction skills really needs to be studied. The problems are: 1) What is the condition of students' communication skills at UniversitasNegeriMedan? 2) What is the condition of students' interaction skills at UniversitasNegeriMedan ? 3) Are there differences in communication skills between men and women? and 4) Are there interactions between men and women? The results obtained can be used as consideration for the university to develop students' communication and interaction skills. In the practice of learning, it is possible that the students' communication skills are 
adequate but the students' interaction skills may not be sufficient. In conditions like this the lecturer needs to provide a larger portion of the student's skills to interact in each lecture compared to communication skills.

\section{Literature Review}

\subsection{Communication Skills}

In general, characters can be interpreted as personality. Masnur Muslich (2011: 71) concludes some opinions about character, namely that characters are related to moral strength, have positive connotations, not neutral ones. Education is building character that means building a character that is related to a positive moral dimension or goodnot negative or bad. From this conclusion it can be seen that education greatly contributes to the development of one's character. In related matters, Elfindri, et al. (2010: 16) explained that the importance of the character formation process so that they have soft skills and are ready to be released to live in the community. Living in a community means that a person is able to devote his knowledge to the community through the work he does. Universities that produce many scholars are certainly not enough if they are only equipped with knowledge and hardskills, but must be balanced with the skills of soft skills to be successful in the workforce. Furthermore, Elfindri, et al. (2010: 156) has stated that there are 19 skills needed by the labor market according to rankings, namely: communication, honesty/integrity, collaboration, interpersonal, good work ethic, motivation, adaptskills, analytical, computer, organization, detail orientation leadership, confidence, courteous, wise, achievement index, creative, humorous, skills, and entrepreneurship. From the description above it is clear that the communication skills of a person ranks first for success in work, while the achievement index as a symbol of one's mastery in certain sciences (hard skills) is only ranked 16. Furthermore, the interaction skills also remains ranked above the communication skills. This can be seen from the interpersonal skills that are ranked fourth. Communication skills are one of the components of a person's soft skills. Communication skills are one's skills to express their intentions and goals to others appropriately. Communication skills consist of several aspects, namely: 1) The skills to recall information conveyed by the other person: the skills to remember information and the correctness of information; 2) Conveying the things that are believed to be true: the skills of a person to maintain the truth of his words, because the untrue facts that are spread will lead to things that are not good; 3) Provide just enough information, because providing more than enough information can saturate and confuse the other person; 4) Selecting the context of the conversation involving the interlocutor (Soelistiyowati and Nugroho (2010: 39-67).

\subsection{Interaction Skills}

The skills of interaction is a component of forming soft skills in addition to communication skills. The interaction skills is the skills of a person to interact socially with the community, including the environment. The skills to interact consists of several aspects, namely: 1) Selection of a safe topicfor conversation: do not choose a topic of conversation that can corner the other person who causes the relationship to be tenuous; 2) The choice of the topic of conversation that is appropriate to the place and situation: the incompatibility of places and situations with the topic of the conversation can make the atmosphere and 
relationship become bad; 3) Adjustment of language, language style and variations: responsiveness to the language used and the variety of languages desired by the interlocutor (Soelistiyowati and Nugroho (2010: 69-94) .The skills of communication and interaction can be developed in daily life by learning and training each day.

\section{Methodology}

The research method used was the ex post facto method (Kerlinger (2006: 604). Data collection tools used were questionnaires. According to UniversitasNegeriMedan statistics, there were 21,364 students (BAAK UNIMED 2012: 27). Determination of the sample used formula from Taro Yamane in Riduwan and Kuncoro (2008: 44), namely: $\mathrm{n}=\mathrm{N} / \mathrm{N} . \mathrm{d} 2+1$; $\mathrm{n}$ $=$ Number of samples; $\mathrm{N}=$ Number of population; $\mathrm{d} 2=$ Femaleecision $(5 \%)$. Then the sample of students in the study was 400 people. women and men of 200. Data collection tools used in this study were questionnaires developed by Soelistiyowati and Nugroho (2012: 139-145). Therefore, a number of items were drawn up which could reveal communication skills and student's interaction skills. The statement items are arranged using a Likert scale model with 8 choices of scale, namely: never, almost never, rarely, sometimes, usually, often, almost always, and always. Reliability coefficient used was 0.726 . Data were analyzed using the SPSS program.

\section{Results And Discussion}

Based on the results of descriptive analysis, communication skills and student interaction skills can be seen in Table 1. Based on Table 1,itshows the average score of communication skills is higher than the average score of student's interaction skills. Based on gender, the description of the data of communication skills and student's interaction skills can be seen in Table 2. Based on Table 2, it shows the average score of communication skills and the skills of male students to interact more than thecommunication skills and interaction skills of female students. Based on the group of knowledge, the description of the data of communication skills and interaction skills of the students of the Natural Sciences group and Social Sciences can be seen in Table 3 .

Table 1.Description of Student Interaction and Communication Skills Data.

\begin{tabular}{ccc}
\hline Variable & X1 & X2 \\
\hline $\mathrm{N}$ & 400 & 400 \\
Mean & 23,05 & 22,09 \\
Median & 23 & 22 \\
Mode & 22 & 20 \\
Std. Deviation & 3,98 & 4,28 \\
Variance & 15,88 & 18,33 \\
Range & 21 & 21 \\
Min. & 11 & 11 \\
Max. & 32 & 32 \\
Min. Ideal & 4 & 4 \\
Max. Ideal & 32 & 32 \\
\hline
\end{tabular}


Explanation:

$\mathrm{X} 1=$ student communication skills

$\mathrm{X} 2=$ student interaction skills

Table 2.Description of Student Interaction and Communication Skills Data based on Gender.

\begin{tabular}{lcccc}
\hline \multicolumn{1}{c}{ Variable } & Male & Female & Male & Female \\
\hline $\mathrm{N}$ & 200 & 200 & 200 & 200 \\
Mean & 23,35 & 22,74 & 22,46 & 21,71 \\
Median & 23 & 22 & 22 & 21 \\
Mode & 25 & 21 & 25 & 18 \\
Std. Deviation & 4,01 & 3,94 & 4,12 & 4,41 \\
Variance & 16 & 15,5 & 16,9 & 19,5 \\
Range & 20 & 20 & 21 & 21 \\
Min. & 12 & 11 & 11 & 11 \\
Max. & 32 & 31 & 32 & 32 \\
Min. Ideal & 4 & 4 & 4 & 4 \\
Max. Ideal & 32 & 32 & 32 & 32 \\
\hline
\end{tabular}

Explanation:

$\mathrm{X} 1$ = student communication skills

$\mathrm{X} 2=$ student interaction skills

Table 3.Description of Interaction and Communication Skills Data based on Major.

\begin{tabular}{|c|c|c|c|c|}
\hline & \multicolumn{2}{|c|}{ X1 } & \multicolumn{2}{|c|}{$\mathrm{X} 2$} \\
\hline & NS & $\mathrm{SS}$ & Male & Female \\
\hline $\mathrm{N}$ & 200 & 200 & 200 & 200 \\
\hline Mean & 23,03 & 23,07 & 22,46 & 21,71 \\
\hline Median & 23 & 23 & 22 & 21 \\
\hline Mode & 24 & 22 & 25 & 18 \\
\hline Std. Deviasi & 4,14 & 3,84 & 4,12 & 4,41 \\
\hline Variance & 17,10 & 14,71 & 16,9 & 19,5 \\
\hline Range & 20 & 21 & 21 & 21 \\
\hline Min. & 12 & 11 & 11 & 11 \\
\hline Max. & 32 & 32 & 32 & 32 \\
\hline Min. Ideal & 4 & 4 & 4 & 4 \\
\hline Max. Ideal & 32 & 32 & 32 & 32 \\
\hline
\end{tabular}

Explanation:

$\mathrm{X} 1=$ student communication skills

$\mathrm{X} 2=$ student interaction skills

$\mathrm{NS}=$ student of the natural science group

$\mathrm{SS}=$ student of social science group

Based on Table 3 shows the average score of the communication skills of natural science students is not much different compared to the average score of Social Science students' 
communication skills. However, the average score of Social Science students' interaction skills is higher than the average science students' skills to interact.

Based on the group of major and gender, the description of the communication skills and student interaction skills data can be seen in Table 4.

Based on Table 4 shows the average score of communication skills of female science students is higher than the communication skills of male science students. The average score of male Social Science students' communication skills is higher than that of female social studies students. Furthermore, the average score of the interaction skills of male science students is not much different from the average score of the interaction skills of female science students. However, the average score of male Social Science students' interaction skills is higher than that of female social studies students.

Table 4.Description of Communication and Interaction skills Data Based on Major and Gender Group.

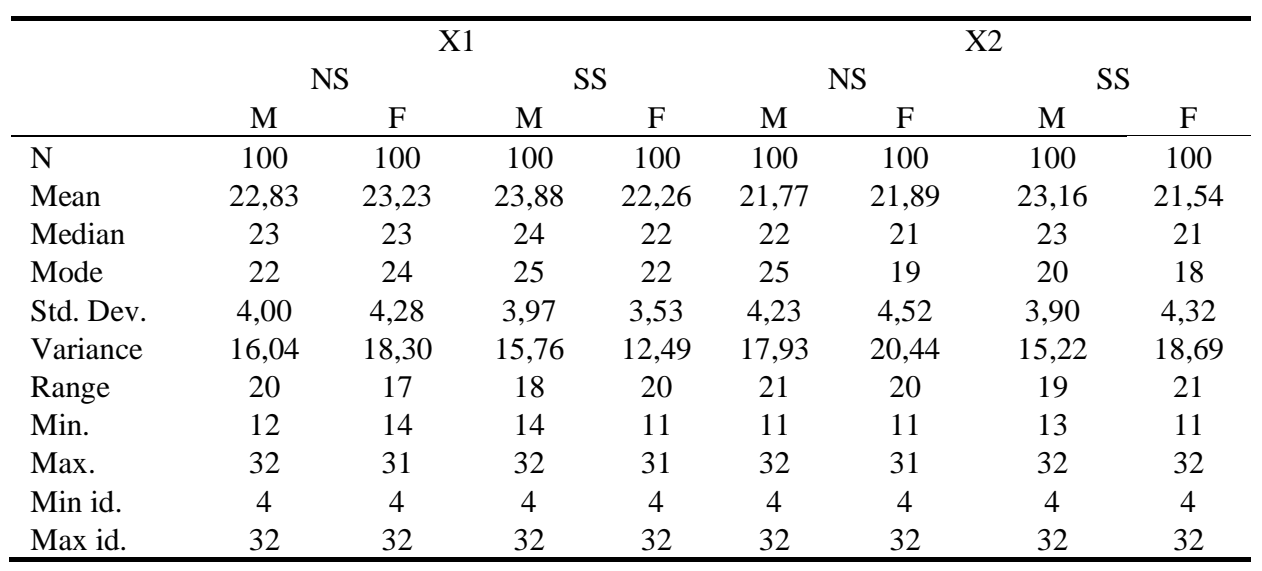

Explanation:

$\mathrm{X} 1=$ student communication skills

$\mathrm{X} 2=$ student interaction skills

$\mathrm{NS}=$ student of the natural science group

$\mathrm{SS}=$ student of social science group

$\mathrm{M}=$ Male

$\mathrm{F}=$ Female

Testing the differences in the average scores of each group can be seen in Table 5.

Table 5.Summary of Communicationand Interaction Skills T-Test Analysis Results based on Major and Gender Group.

\begin{tabular}{lcccc}
\hline \multicolumn{1}{c}{ Skills and Group } & $\mathbf{t}_{\text {count }}$ & $\begin{array}{c}\boldsymbol{\alpha} \\
\text { observation }\end{array}$ & $\begin{array}{c}\boldsymbol{\alpha} \\
\text { table }\end{array}$ & Explanation \\
\hline $\begin{array}{l}\text { Communication } \\
\text { of Skills }\end{array}$ & & & & \multicolumn{1}{c}{ Not } \\
$\begin{array}{l}\text { Female and Male } \\
\text { student }\end{array}$ & 1,552 & 0,12 & 0,05 & significant \\
\hline
\end{tabular}




\begin{tabular}{|c|c|c|c|c|}
\hline $\begin{array}{l}\text { Communication Skills } \\
\text { of } \\
\text { Student Social Science } \\
\text { and Natural Science }\end{array}$ & 0,099 & 0,92 & 0,05 & $\begin{array}{c}\text { Not } \\
\text { significant }\end{array}$ \\
\hline $\begin{array}{l}\text { Communication Skills } \\
\text { of } \\
\text { Natural } \\
\text { Female and } \\
\text { Student }\end{array}$ & 0,658 & 0,512 & 0,05 & $\begin{array}{c}\text { Not } \\
\text { significant }\end{array}$ \\
\hline $\begin{array}{l}\text { Communication Skills } \\
\text { of } \\
\text { Student of Social } \\
\text { Science Female and } \\
\text { Male }\end{array}$ & 3,373 & 0,001 & 0,05 & Significant \\
\hline $\begin{array}{l}\text { Interaction Skills of } \\
\text { Female and Male } \\
\text { student }\end{array}$ & 1,736 & 0,08 & 0,05 & $\begin{array}{c}\text { Not } \\
\text { significant }\end{array}$ \\
\hline $\begin{array}{l}\text { Interaction Skills of } \\
\text { Student Social Science } \\
\text { and Natural Science }\end{array}$ & 1,159 & 0,248 & 0,05 & $\begin{array}{c}\text { Not } \\
\text { significant }\end{array}$ \\
\hline $\begin{array}{l}\text { Interaction Skills of } \\
\text { Natural Science } \\
\text { Female and Male } \\
\text { Student }\end{array}$ & 0,181 & 0,856 & 0,05 & $\begin{array}{c}\text { Not } \\
\text { significant }\end{array}$ \\
\hline $\begin{array}{l}\text { Interaction Skills of } \\
\text { Student of Social } \\
\text { Science Female and } \\
\text { Male }\end{array}$ & 2,971 & 0,004 & 0,05 & Significant \\
\hline
\end{tabular}

Based on Table 5 shows the communication skills of female Social Science students differ significantly from the skillsofmale social science. This means that the communication skills of female Social Science students are better than those of male Social Science students. Then, theinteractionskills of female Social Science student differed significantly from the social science interaction skills of malestudents. This also gives the meaning of the skills of female Social Science students to interact better than male Social Science students.

Based on descriptive analysis and the t-test conducted, it can provide the following description. First, students' communication and interaction skillstend to be in the medium category. This finding supports of Dahlan Nariman's (2013: 1) explanationwhich suggests that the important factors that should receive attention are the soft skills of students which include communication skills. Research on students'communication skills in schools has received attention since several decades ago, such as Ndongko and Agu (1985: 205) suggesting that students communication in class correlates with their academic behavior. These findings also provide clues that efforts to improve communication skills are needed for students. Efforts to improve category communication skills are being carried out by improving information processing skills when communicating, while efforts to increase interaction skills category are being carried out in an effort to follow the changes in one's speech style. Soelistiyowati and Nugroho (2012: 149-150). In the 4.0 industry revolution era now it is not enough to rely solely on academic skills, but must have high communication skills and interaction skills. Hidayatullah (2010: 111) suggested that students as prospective leaders must have and study 
in higher education, expected to prepare themselves especially those related to personal development and character. Second, in general the communication skills of female and male students are not significantly different. This provides guidance if the efforts to improve communication skills are carried out through training, that male and female students can be placed in the same group. These results provide support for the research results of Sitanggang and Saragih (2007: 46) which found that student characteristics (emotional stskills, extraversion, openness, conscience and prudence) of male upper secondary school students did not differ significantly compared to females in Medan City. Third, based on the group of science and gender, the communication skills of the students of Social Science for women and men differed significantly, and the value of $t=3.373$ with $\alpha=0.001<0.05$. These results are reinforced by descriptive analysis which shows that the communication skills of male Social Science group students scored an average score of 23.35 or greater than the communication skills of female social science students who obtained an average score of 22.74 . Therefore it was concluded that the communication skills of male Social Science students were higher than female Social Science students. These results provide support for the research results of Sitanggang and Saragih (2008: 46) which found that male high school students are more responsible than women and male Vocational High School students are more independent and responsible than women. This finding also supports the findings of Robbins and Coulter (2007: 330) that there are differences in the communication styles of men and women, men are accustomed to speaking in order to emphasize status, while women use talks tocreate relationships. Fourth, the interaction skills of female and male Social Science students was significantly different, and the value of $\mathrm{t}=2.971$ with $\alpha=0.004<0.05$. These results are reinforced by descriptive analysis which shows that the interaction skills of male Social Science group students scored an average score of 22.46 or greater than the interaction skills of female Social Science group students who obtained an average score of 21.71. Therefore it was concluded that the male social science student's interaction skills was higher than female Social Science students. This provides a clue if efforts to improve interaction skills are carried out through training, that students of the Social Science group of women are not placed in the same class as men. Based on the research findings, the College needs to map the communication and interaction skills of students to find out the real picture.

\section{Conclusion}

The results found prove that differences in communication skills and student interaction skills depend on the group of major and gender. Communication and interaction skills of each student need to be improved continuously. Students in the current Industrial Revolution 4.0 era are not enough to rely solely on academic skills, but must have high communication and interaction skills. To improve student communication and interaction skills, it can be done through training by conducted personally or institutionally with the following efforts: (1) Familiarize yourself with saying something properly according to the topic of the conversation; (2) Familiarize yourself with processing information well when communicating with others; (3) Familiarize yourself with the thoughts of others; and (4) Trying to follow the changes in other people's speech styles. 


\section{Acknowledgement}

Thank you to the Directorate of Research and Community Service Ministry of Research, Technology and Higher Education who have provided research funding through the Higher Education Leading Research scheme and the leaders of the Medan State University who have given permission so that this research can be carried out properly.

\section{References}

[1]Dahlan, Nariman., Melamar Kerja di Jepang Bukan Dilihat Femaleestasi Akademisnya. Accessed from Kompas.com, Wednesday, June 26th, 2013.

[2]Elfindri, et al., Soft Skills untuk Pendidik. Baduose Media,2010.

[3]Hidayatullah, Furqon., Pendidikan Karakter: Membangun Peradaban Bangsa. Surakarta: Yuma Pustaka, 2010

[4]Kerlinger, Fred N.,Foundation of Behavioral Research.Third edition.Holth, Rinehart and Winston Inc, 1986 .

[5]Masnur Muslich, Pendidikan Karakter. Jakarta: Bumi Aksara Publisher, 2011.

[6]Ndongko, Theresa M. and A.A. Agu.,"The Impact of Communication on the Learning Femaleocess: A Study of Secondary School in Calabar Municipality, Cross River State of Nigeria." Journal International Review of Education, Volume 31, Issue 1, pp. 205-221, 1985.

[7]Panduan Pelaksanaan Penelitian dan Pengabdian Kepada Masyarakat di Perguruan Tinggi Edition

IX. Jakarta: Directorate General of Higher Education,Ministry of Education and Culture, 2013.

[8]Riduwan and Kuncoro, Engkos Achmad, Cara Menggunakan dan Memaknai Analisis Jalur (Path Analysis).Bandung: Alfabeta Publisher, 2008.

[9]Robbins, Stephen P. And Mary Coulter, Management. New Jersey: Pearson Education, Inc, 2007.

[10]Sitanggang, Nathanael and Saragih, Abd. Hasan., "Studi Karakteristik Siswa SLTA di Kota Medan.” Jurnal Penelitian Bidang Pendidikan, Vol. 14, No. 1, 2007.

[11]Soelistiyowati, Endang and Nugroho, Vincent ., Strategi Komunikasi untuk Sukses Menjalin Relasi. Jakarta: PT. Gramedia Pustaka Utama, 2012.

[12]The Character Building University Data Personil Tahun 2013. Medan: BAUK UNIMED, 2013 